\title{
10. OXYGEN AND HYDROGEN ISOTOPE RATIOS OF INTERSTITIAL WATERS FROM AN INTRAPLATE DEFORMATION AREA: BENGAL FAN, LEG 116 1
}

\author{
J. Boulègue ${ }^{2}$ and T. Bariac ${ }^{3}$
}

\begin{abstract}
The oxygen and hydrogen isotope compositions of pore waters are controlled by several processes: (1) hyperfiltration-osmotic effects, (2) carbonate deposition, (3) reaction with volcanic ash, and (4) mixing with water that has reacted with basaltic basement. These data are useful to supplement information obtained from shipboard chemical analyses.
\end{abstract}

\section{INTRODUCTION}

Fluid circulation believed to result from the effects of intraplate deformation was observed during Leg 116 in the central Indian Ocean (Shipboard Scientific Party, 1989a, b, c). In this same area, large heat transfers were attributed to expulsion of fluids (Geller et al, 1983). Oxygen and hydrogen isotopic ratios offer the possibility of qualifying and assessing some of the water-rock interactions that may occur during the expulsion of fluids and the reactions of interstitial waters with sediments.

\section{SAMPLING AND ANALYSIS}

The interstitial waters were collected in sealed glass containers immediately after extraction. The available amounts were between 0.3 and $1.5 \mathrm{~cm}^{3}$. This procedure avoids evaporation and consequent artificial isotopic fractionation on samples. Isotopic analyses were performed using different techniques:

1. For ${ }^{18} \mathrm{O} /{ }^{16} \mathrm{O}$ analysis we used the classical method of equilibration of water with $\mathrm{CO}_{2}$ at $25^{\circ} \mathrm{C}$ (Epstein and Mayeda, 1953).

2. For ${ }^{2} \mathrm{H} /{ }^{1} \mathrm{H}$ the technique of reduction of the water on uranium at $800^{\circ} \mathrm{C}$ was used (Bigeleisen et al., 1952).

The isotopic ratios ${ }^{18} \mathrm{O} /{ }^{16} \mathrm{O}$ and ${ }^{2} \mathrm{H} /{ }^{1} \mathrm{H}$ were measured by mass spectrometer (Finnigan Delta E). The isotopic ratios are recorded using the $\delta$ notation relative to the international standard V-SMOW (Standard Mean Ocean Water).

$$
\delta=\left[\left(R_{\text {sample }} / R_{\text {reference }}\right)^{-1}\right] \times 10^{3}
$$

where $R={ }^{18} \mathrm{O} /{ }^{16} \mathrm{O}$ or ${ }^{2} \mathrm{H} /{ }^{1} \mathrm{H}$.

The analysis error of the $\delta^{18} \mathrm{O}$ measurement is $0.1 \%$ in the case of the $\mathrm{CO}_{2}$ equilibration method and $0.5 \%$ for the $8^{2} \mathrm{H}$ measurement.

A check on the quality of the extraction procedure can be done by comparing two adjacent samples from Site 719 , in the same type of sediment: one at 118.2 mbsf with the BarnesUyeda in-situ pore-water sampler, one at $119.7 \mathrm{mbsf}$ with the regular ODP procedure. The results for $\delta^{18} \mathrm{O}$ are only $0.04 \%$

\footnotetext{
${ }^{1}$ Cochran, J. R., Stow, D.A.V., et al., 1990. Proc. ODP, Sci. Results, 116: College Station, TX (Ocean Drilling Program).

2 Laboratoire de Gèochimie et Mètallogènie, CNRS URA 196, UPMC, 4 Place Jussieu, 75005 Paris, France.

${ }^{3}$ Laboratoire de Biogèochimie Isotopique, CNRS URA 196, UPMC, 4, Place Jussieu, 75005 Paris, France.
}

apart and for $\delta \mathrm{D}$ they are only $0.36 \%$ apart. This is well within analytical uncertainty.

\section{RESULTS AND DISCUSSION}

The results are given in Tables 1-3 and Figures 1 and 2 . Each of the sites seem to have some characteristics in common as well as some differences with the others. We first discuss some results concerning $\delta^{2} \mathrm{H}$, then discuss $\delta^{18} \mathrm{O}$ for each hole, and finally present a general discussion on processes controlling oxygen and hydrogen isotope compositions.

\section{Hydrogen Isotopes Compositions}

As seen in Figure 1, $\delta^{2} \mathrm{H}$ tends to decrease with depth. Most of the data are within $\pm 1.5 \%$ of a line with slope $d\left(\delta^{2} \mathrm{H}\right) / d z=-6 \% d \mathrm{~km}$. Only a few points depart from this trend: 276.7 and 306.8 mbsf for Site 718 and 60, 205, and 233 mbsf for Site 719; we will discuss these further.

In the sedimentary environment of the southern extremity of the Bengal Fan, there are few possibilities that explain the decrease of $\delta^{2} \mathrm{H}$ with depth. Alteration of volcanic ash in the sediment column, and/or of basalt from the basement, is one of the effects that may deplete the composition of the pore waters in $\delta^{2} \mathrm{H}$, although this is very difficult to assess (Laurence, 1989). Another possibility is the hyperfiltration effect and related osmotic fluid movements by the compacting clay-rich layers found sandwiched between silt-sand layers (Coplen and Hanshaw, 1973). The broad implication is that there should be a relationship between $\delta^{2} \mathrm{H}$ and $\delta^{18} \mathrm{O}$ related to this effect. This is indeed what we find, as discussed later; hence the ultrafiltration-osmotic effects may be active in sediments from Leg 116. These effects may have been more acute in some samples, which may explain the points outside of the correlation area of Figure 1 (except for 60 mbsf at Site 719. We think that this last exception can be related to expulsion of interlayer water of montmorillonite (Laurence, 1989).

\section{$\delta^{18} \mathrm{O}$ at Site 717 (Fig. 3)}

From 0 to $250 \mathrm{mbsf}$ the oxygen isotope compositions of the pore water are almost constant. This is in contrast to the results obtained from previous DSDP legs (Laurence, 1989), where $\delta^{18} \mathrm{O}$ is generally found to decrease with increasing depth. This decrease may be due to precipitation of carbonates in the upper part of Site 717 (Shipboard Scientific Party, 1989a). The expulsion of interlayer water of montmorillonite may also have been effective. Between 242 and 270.5 mbsf 
Table 1. Oxygen isotope ratios $\left(\delta^{18} \mathrm{O}\right)$ in \%o vs. V-SMOW), hydrogen isotope ratios $\left(\delta^{2} \mathrm{H}\right.$ in $\%$ vs. V-SMOW) of pore waters at Site 717. Ca, $\mathrm{Mg}$, and $\mathrm{Cl}$ in $\mathrm{mM}$ are also given.

\begin{tabular}{cccccl}
\hline $\begin{array}{c}\text { Depth } \\
\text { (mbsf) }\end{array}$ & $\mathrm{Ca}$ & $\mathrm{Mg}$ & $\mathrm{Cl}$ & $\delta^{18} \mathrm{O}$ & $\delta^{2} \mathrm{H}$ \\
\hline 6 & 10.25 & 49.08 & 557 & -0.2 & -4 \\
66.5 & 6.53 & 40.16 & 560 & -0.2 & -3 \\
104.5 & 6.8 & 40.38 & 558 & -0.2 & -3.7 \\
242 & 7.34 & 36.72 & 556 & -0.2 & -5.25 \\
270.5 & 9.49 & 39.62 & 532 & -0.9 & -3.5 \\
325 & 12.18 & 33.09 & 544 & -0.55 & -5.4 \\
365.5 & 14.27 & 33.27 & 521 & -1 & -4.7 \\
422.5 & 16.23 & 33.25 & 525 & -1 & -7 \\
449.5 & 16.71 & 30.57 & 529 & -1.1 & -6 \\
479.5 & 17.17 & 29.35 & 505 & -1.55 & -6.8 \\
508 & 16.03 & 26.49 & 552 & -1.5 & -7.3 \\
533.5 & 17.77 & 32.34 & 505 & -1.45 & -6.65 \\
571.4 & 17.09 & 30.02 & 559 & -1 & -5.95 \\
631.5 & 16.57 & 25.67 & 554 & -1.3 & -6.7 \\
665 & 17.13 & 26.25 & 568 & -1.5 & -8.3 \\
761.5 & 18.34 & 21.22 & 568 & -1.3 & -6.6 \\
788.5 & 18.85 & 20.95 & 570 & -1.4 & -8.7 \\
823.2 & 22.46 & 18.66 & 557 & -1.2 & -7 \\
\hline
\end{tabular}

Table 2. Oxygen isotope ratios $\left(\delta^{18} \mathrm{O}\right.$ in \%o vs. V-SMOW), hydrogen isotope ratios $\left(\delta^{2} \mathrm{H}\right.$ in \%o vs. V-SMOW) of pore waters at Site 718. Ca, $\mathrm{Mg}$, and $\mathrm{Cl}$ in $\mathrm{mM}$ are also given.

\begin{tabular}{rlllll}
\hline $\begin{array}{r}\text { Depth } \\
\text { (mbsf) }\end{array}$ & $\mathrm{Ca}$ & $\mathrm{Mg}$ & $\mathrm{Cl}$ & $\delta^{18} \mathrm{O}$ & $\delta^{2} \mathrm{H}$ \\
\hline 1.5 & 10.61 & 52.26 & 555 & -0.25 & -2 \\
4.5 & 10.4 & 50.03 & 548 & -0.4 & -4.4 \\
90.5 & 11.19 & 49.9 & 560 & -0.55 & -3.7 \\
107.3 & 10.75 & 47.06 & 558 & -0.2 & -4.3 \\
124.8 & 10.63 & 44.85 & 569 & -0.2 & -2.6 \\
162.8 & 10.7 & 42.25 & 531 & -0.9 & -4.7 \\
191.3 & 12.72 & 41.94 & 540 & -0.9 & -4.5 \\
238.8 & 11.24 & 30.28 & 555 & -1 & -5.7 \\
276.7 & 11.75 & 32 & 570 & -1.2 & -7.2 \\
306.8 & 11.98 & 32.73 & 569 & -1 & -7.5 \\
418.9 & 14.45 & 29.82 & 570 & -1.2 & -6.2 \\
428.8 & 14.71 & 30.29 & 571 & -1 & -6.8 \\
495.7 & 14.66 & 28.75 & 569 & -1.2 & -6.8 \\
525.3 & 15.08 & 28.27 & 584 & -1.15 & -6.9 \\
593.3 & 15.52 & 25.3 & 584 & -1.3 & -7.3 \\
647.3 & 16.94 & 26.22 & 578 & -1.6 & -7.7 \\
704.3 & 17.54 & 24.67 & 583 & -1.6 & -8.4 \\
800 & 17.42 & 20.36 & 588 & -1.6 & -8 \\
856.3 & 16.71 & 28.51 & 563 & -1 & -7.7 \\
893.5 & 20.06 & 27.4 & 556 & -1.4 & -8.5 \\
920 & 19.55 & 18.72 & 584 & -1.7 & -10.5 \\
& & & & &
\end{tabular}

there is a marked decrease of $\delta^{18} \mathrm{O}\left(\Delta \delta^{18} \mathrm{O}=-0.7 \%\right.$ ) . This depth range is well within lithologic Unit III, which is a relatively uniform sequence of mud and biogenic turbidites (Shipboard Scientific Party, 1989a). Below $270.5 \mathrm{mbsf}$, $\delta^{18} \mathrm{O}$ decreases steadily with depth, with most of the samples corresponding to $-1.4 \pm 0.3 \%$ and $d \delta^{18} \mathrm{O} / d z=-0.7 \% o / \mathrm{km}$. However, some samples between 479.5 and 533.3 mbsf have more negative values of $\delta^{18} \mathrm{O}$ that may be due either to alteration of volcanic ash or basaltic basement and/or ultrafiltration-osmotic effects.

\section{$\delta^{18} \mathrm{O}$ at Site 718 (Fig. 4)}

Near 90 mbsf there is a slight decrease of $\delta^{18} \mathrm{O}$ relative to surficial values at $107.3-124.4 \mathrm{mbsf} ; \delta^{18} \mathrm{O}$ values are again the same as at $1.5 \mathrm{mbsf}$. The lower values at 90 mbsf may be due to upwelling of deep water as discussed on the basis of the major-element composition of pore waters (Shipboard Scientific Party, 1989b). Between 124.8 and 162.8 mbsf there is a
Table 3. Oxvgen isotope ratios $\left(\delta^{18} \mathrm{O}\right.$ in $\%$ vs. V-SMOW), hydrogen isotope ratios $\left(\delta^{2} \mathbf{H}\right.$ in \%o vs. V-SMOW) of pore waters at Site 719. Ca, $\mathrm{Mg}$, and $\mathrm{Cl}$ in $\mathrm{mM}$ are also given.

\begin{tabular}{cccccc}
\hline $\begin{array}{c}\text { Depth } \\
\text { (mbsf) }\end{array}$ & $\mathrm{Ca}$ & $\mathrm{Mg}$ & $\mathrm{Cl}$ & $\delta^{18} \mathrm{O}$ & $\delta^{2} \mathrm{H}$ \\
\hline 3 & 10.3 & 49.45 & 555 & -0.2 & -3.95 \\
60 & 6.71 & 41.65 & 558 & 0 & -0.6 \\
118.2 & 5.74 & 43.03 & 558 & -0.5 & -4.5 \\
119.7 & 5.11 & 40.65 & 554 & -0.5 & -4.2 \\
181.2 & 7.71 & 43.86 & 539 & -0.7 & -3.5 \\
205 & 8.48 & 42.14 & 525 & -1.7 & -7.2 \\
233 & 9.48 & 35.02 & 562 & -1.45 & -8.2 \\
283.7 & 11.13 & 34.74 & 528 & -1.7 & -6.4 \\
320.7 & 14.04 & 28.86 & 559 & -1.5 & -7 \\
435 & 16.13 & 25.25 & 568 & -1.6 & -6.8 \\
\hline
\end{tabular}

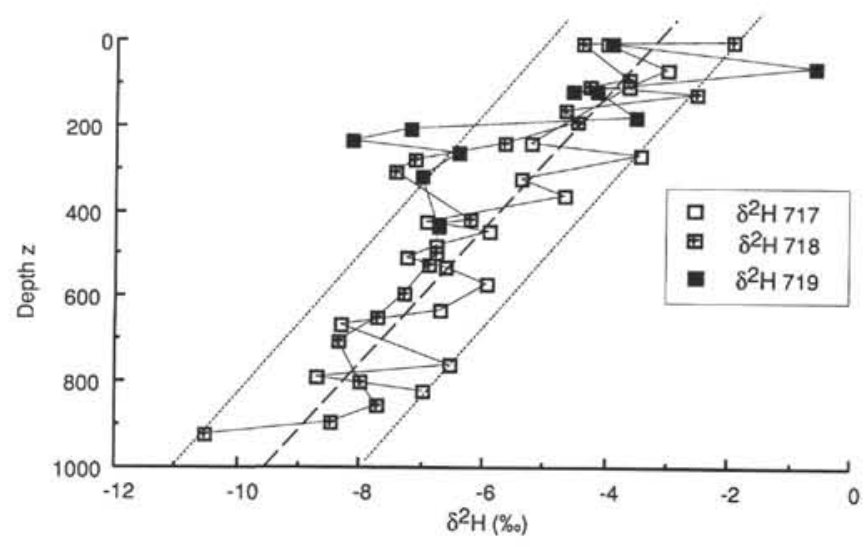

Figure $1 . \delta^{2} \mathrm{H}(\% \circ$ vs. SMOW) in pore waters of Sites 717,718 , and 719 vs. depth $(\mathrm{z}, \mathrm{mbsf})$. The dashed line corresponds to $d \delta^{2} \mathrm{H} / d z=$ $-6 \% \mathrm{~km}$, and is bordered by dotted lines at $\pm 1.5 \%$.

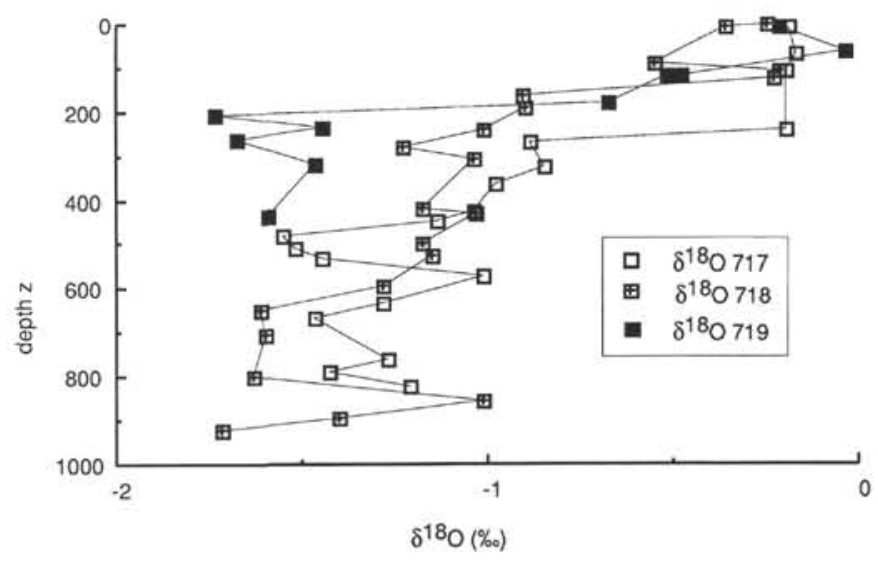

Figure 2. $\delta^{18} \mathrm{O}$ (\%ovs. SMOW) in pore waters of Sites 717, 718, and 719 vs. depth (z, mbsf).

decrease of $\delta^{18} \mathrm{O} ; \Delta \delta^{18} \mathrm{O}=-0.7 \%$. As for Site 717 , this decrease occurs within the mud turbidites of lithologic Units IIl-IV. Between 162.8 and 593 mbsf there is a steady decrease of $\delta^{18} \mathrm{O}$ with increasing depth, following the slope $d \delta^{18} \mathrm{O} / d z 0.7 \% \mathrm{om}$. There is offset, about $-0.35 \%$, between 593.3 and $647.3 \mathrm{mbsf}$, and below this the decrease of ${ }^{18} \mathrm{O}$ is again following $d \delta^{18} \mathrm{O} / d z$ $-0.7 \%$ o $\mathrm{km}$. Only one point at $856.3 \mathrm{mbsf}$ deviates significantly from this trend in the lower zone: where an increase in the ${ }^{18} \mathrm{O}$ content of the pore water is found in an area where upwelling 


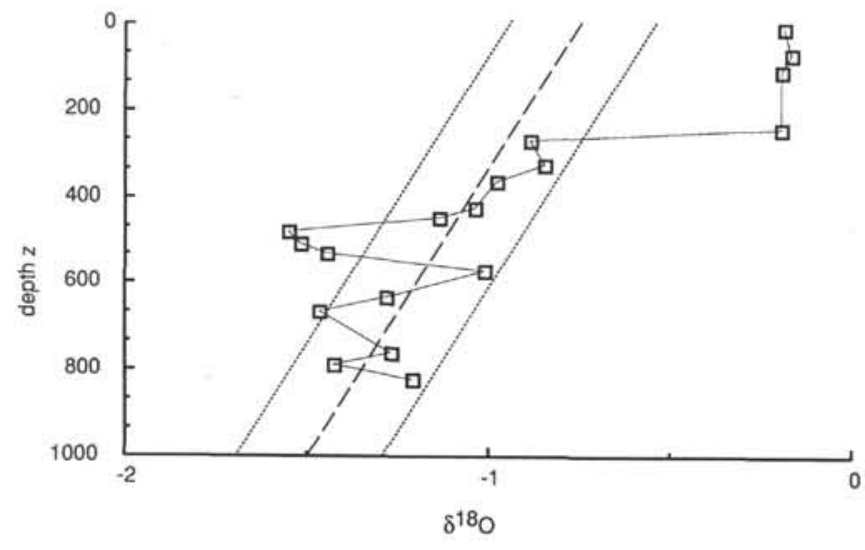

Figure 3. $\delta^{18} \mathrm{O}$ (\%० vs. SMOW) in pore waters of Site 717 vs. depth (z, mbsf). The dashed line corresponds to $d \delta^{18} \mathrm{O} / d z=-0.7 \% d \mathrm{~km}$, and it is bordered by dotted lines at $\pm 0.2 \%$.

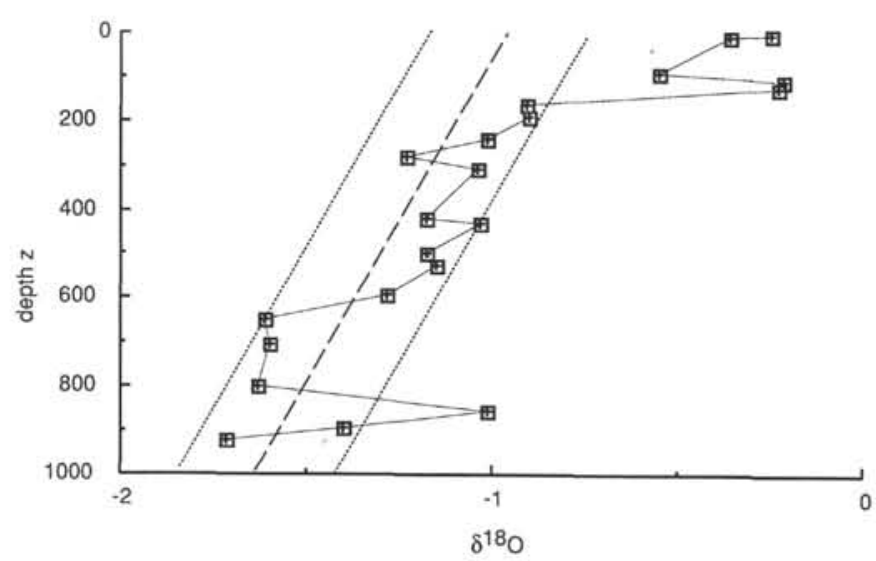

Figure 4. $\delta^{18} \mathrm{O}(\% \circ$ vs. SMOW) in pore waters of Site $718 \mathrm{vs}$. depth $(\mathrm{z}$, mbsf). The dashed line corresponds to $d \delta^{18} \mathrm{O} / d z=-0.7 \% \mathrm{~km}$, and it is bordered by dotted lines at $\pm 0.2 \%$.

of hot water was inferred from the major-elements composition of the pore waters (Shipboard Scientific Party, 1989b). We believe that the hot fluid may have been derived from interaction of pore waters with the basement. The shift toward higher ${ }^{18} \mathrm{O}$ implies high-temperature $\left(150-200^{\circ} \mathrm{C}\right)$ interaction of the basalt with seawater. This point will be discussed further.

\section{$\delta^{18} \mathrm{O}$ in Hole 719}

The $\delta^{18} \mathrm{O}$ data from Site 719 are quite similar to the $\delta^{2} \mathrm{H}$ plotted vs. depth. At $60 \mathrm{mbsf}$ there is an increase of ${ }^{18} \mathrm{O}$. Between 181.2 and 205 mbsf there is an offset toward more negative ${ }^{18} \mathrm{O}: \Delta \delta^{18} \mathrm{O}=1 \%$. Again as at Sites 717 and 718 , this offset is located in mud turbidites within lithologic Unit III, near the boundary between Units III and IV. Deeper within the section, $\delta^{18} \mathrm{O}$ are more negative than in Sites 717 and 718 and they are scattered, so that it is difficult to assess how closely they follow the $d \delta^{18} \mathrm{O} / d z-0.7 \%$ o $/ \mathrm{km}$ found at Sites 717 and 718. These values appear to be almost the same: $-1.6 \pm$ $0.15 \%$. Between 205 and 435 mbsf the values of $\delta^{18} \mathrm{O}$ in Site 719 are more negative than in Sites 717 and 718 for the same depth range. This may be due to more intense diagenetic and/or ultrafiltration-osmotic effects.

\section{Lithologic Effects}

Comparison of $\delta^{18} \mathrm{O}$ values for sediment layers that can be accurately correlated between sites on the basis of the same

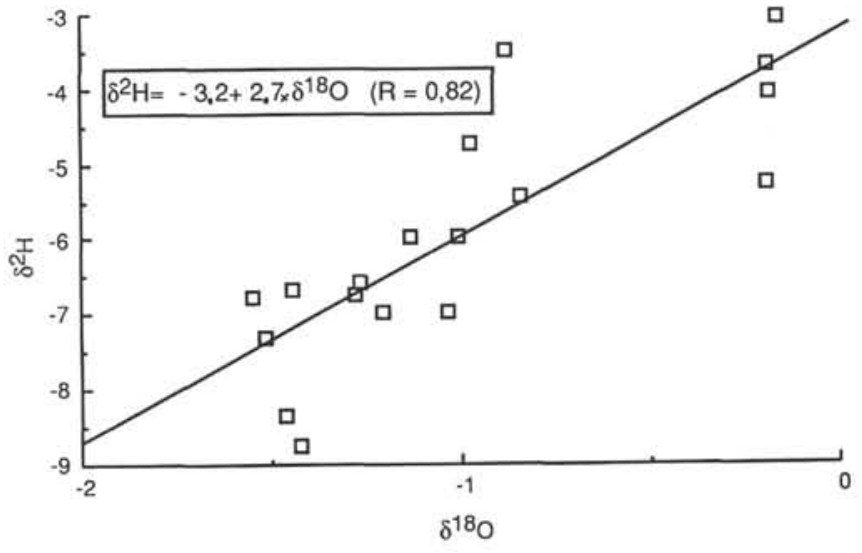

Figure 5. $\delta^{2} \mathrm{H}$ vs. $\delta^{18} \mathrm{O}(\% \circ$ vs. SMOW) in Site 717 pore waters, with regression line.

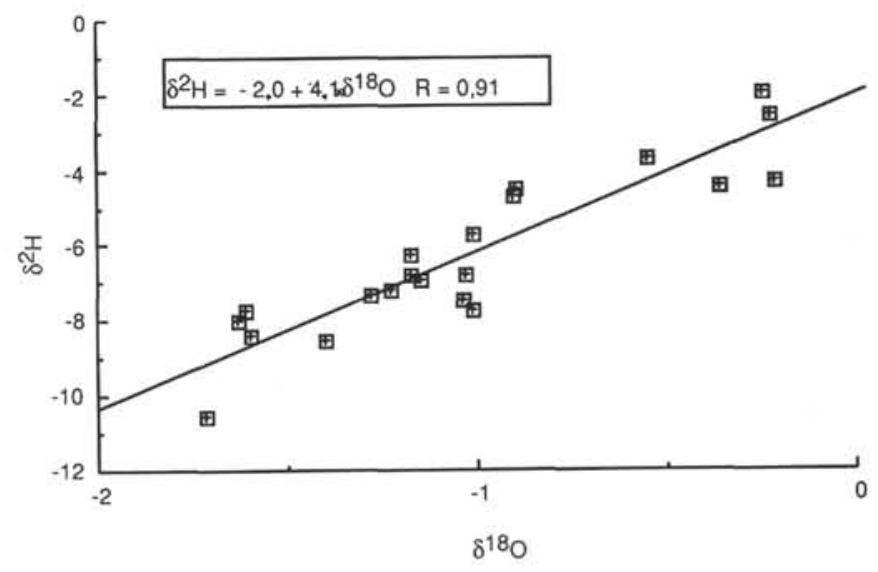

Figure 6. $\delta^{2} \mathrm{H}$ vs. $\delta^{18} \mathrm{O}(\%$ vs. SMOW) in Site 718 pore waters, with regression line.

age and lithology, can be done in several cases: six between Sites 717 and 718; five between Sites 717 and 719, and three between Sites 718 and 719 . Among these 16 possibilities, only two show closely similar data for both $\delta^{18} \mathrm{O}$ and $\delta^{2} \mathrm{H}$ at the corresponding levels. The first of these (571.4 mbsf in Site 717 and 191.3 mbsf in Site 718) correspond to levels that are within the general trends outlined above. In this case the values of $\delta^{18} \mathrm{O}$ and $\delta \mathrm{D}$ are relatively close, the range of difference being within the range of the analytical error for $\delta^{18} \mathrm{O}$ and three times the analytical error for $\delta \mathrm{D}$. In the second case $(761.5 \mathrm{mbsf}$ in Site 717 and 418.9 mbsf in Site 718) the differences between the data are smaller than the analytical error, so that the agreement is presumably significant. This case also corresponds to points well within the $\delta^{18} \mathrm{O}$-depth and $\delta^{2} \mathrm{H}$-depth trends described above. It is clear, therefore, that only few levels within the sediments of Leg 116 sites may have a $\delta^{18} \mathrm{O}$ and $\delta^{2} \mathrm{H}$ evolution that might be directly influenced by the lithology. This is perhaps not surprising because upwelling of water is thought to occur on a large scale at Site 718 and only in the deepest level at Site 717 (Shipboard Scientific Party, $1989 \mathrm{a}, \mathrm{b})$.

\section{$\delta^{18} \mathrm{O}-\delta^{2} \mathrm{H}$ Relationships}

Some of the effects we have discussed above imply a relationship between $\delta^{18} \mathrm{O}$ and $\delta^{2} \mathrm{H}$. The $\delta^{18} \mathrm{O}-\delta^{2} \mathrm{H}$ diagrams for each hole are given in Figures 5, 6, and 7.

The process of alteration of basalt and/or volcanic ash seems unlikely to have caused the $\delta^{18} \mathrm{O}-\delta^{2} \mathrm{H}$ relationship 


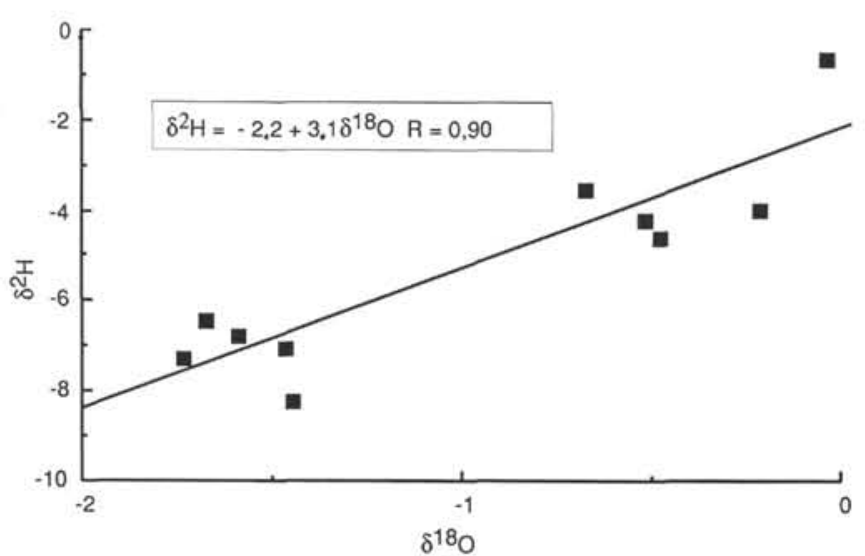

Figure $7 . \delta^{2} \mathrm{H}$ vs. $\delta^{18} \mathrm{O}$ (\%o vs. SMOW) in Site 719 pore waters, with regression line.

observed. The membrane filtration effect should give a relationship with $d \delta^{2} \mathrm{H} / d \delta^{18} \mathrm{O}=3.12$, following the results of Coplen and Hanshaw (1973). At Site 717, $\delta^{2} \mathrm{H}=-3.9 \pm 2.75$ $\times \delta^{18} \mathrm{O}$ and at Site $719, \delta^{2} \mathrm{H}=-2.18 \pm 3.11 \times \delta^{18} \mathrm{O}$. As both of these relationships are close to that predicted, osmotic effects did indeed play a role in controlling the ${ }^{18} \mathrm{O} /{ }^{16} \mathrm{O}$ and ${ }^{2} \mathrm{H} /{ }^{1} \mathrm{H}$ behavior at both sites. At Site $718, \delta^{2} \mathrm{H}=-2.01 \pm 414$ $\times \delta^{18} \mathrm{O}$. Although this last relationship is statistically significant, it is more difficult to relate it to any particular process.

\section{$\delta^{18} \mathrm{O}-\mathrm{Cl}$ and $\delta^{2} \mathrm{H}-\mathrm{Cl}$ Relationships}

Comparison of $\delta^{18} \mathrm{O}$ and $\delta^{2} \mathrm{H}$ with the $\mathrm{Cl}$ data leads to two main conclusions:

1. The decrease of $\mathrm{Cl}$ found in the clay layers is indeed accompanied by a decrease of $\delta^{18} \mathrm{O}$ and $\delta^{2} \mathrm{H}$. For Sites 717 and $718, d \delta^{18} \mathrm{O} / d \mathrm{Cl} 0.03 \% \circ \mathrm{mM}^{-1}$ and for Site $719, d \delta^{18} \mathrm{O} / d \mathrm{Cl} 0.05 \%$ $\mathrm{mM}^{-1}$. These relationships also imply that the membrane filtration and related osmotic effects may have been active in Leg 116 sediments.

2. At both Sites 717 and 719 the $\delta^{18} \mathrm{O}$ and $\delta^{2} \mathrm{H}$ values of adjacent clay and sand rich layers with very different $\mathrm{Cl}$ values are almost the same, whereas at Site 718 the $\delta^{2} \mathrm{H}$ and $\delta^{18} \mathrm{O}$ values in the sand layers are lower than those in the clay layers. This difference in behavior, we suggest, is related to upwelling and expansion of hot water at Site 718.

\section{$\delta^{18} \mathrm{O}$-Ca Relationships}

The $\delta^{18} \mathrm{O}-\mathrm{Ca}$ relationships for each hole are given in Figures 8,9 , and 10 . In hole 717 the main features are as follows (Fig. 8).

1. In the upper part, at levels 66.5 to $242 \mathrm{mbsf}$, there is a decrease in Ca with little change in $\delta^{18} \mathrm{O}$. This is in agreement with the diagenetic formation of $\mathrm{CaCO}_{3}$ deduced from the shipboard pore-water data (Shipboard Scientific Party, 1989a).

2. A decrease of $\delta^{18} \mathrm{O}$ between 242 and $270.5 \mathrm{mbsf}$, which was already noticed; this will be discussed further.

3. Between 270.5 and $422.5 \mathrm{mbsf}$, there is an increase in $\mathrm{Ca}$ and a slight decrease in $\delta^{18} \mathrm{O}$. We interpret this as a pore-water mix along a tie line (line " 3 "' in the $\mathrm{Ca}-\delta^{18} \mathrm{O}$ diagram) between a pore water similar to that found at $270.7 \mathrm{mbsf}$ and one similar to that found at 823.2 mbsf (point $\alpha$ in Fig. 8).

4. A decrease of $\delta^{18} \mathrm{O}$ with almost constant $\mathrm{Ca}$ between 422.5 and 665 mbsf (area " 4 " in Fig. 8). The two extreme compositions correspond to pore waters at 479.5 and 571.4 mbsf. Area (4) can be characterized by a mean $d \delta^{18} \mathrm{O} / d \mathrm{Ca}=$

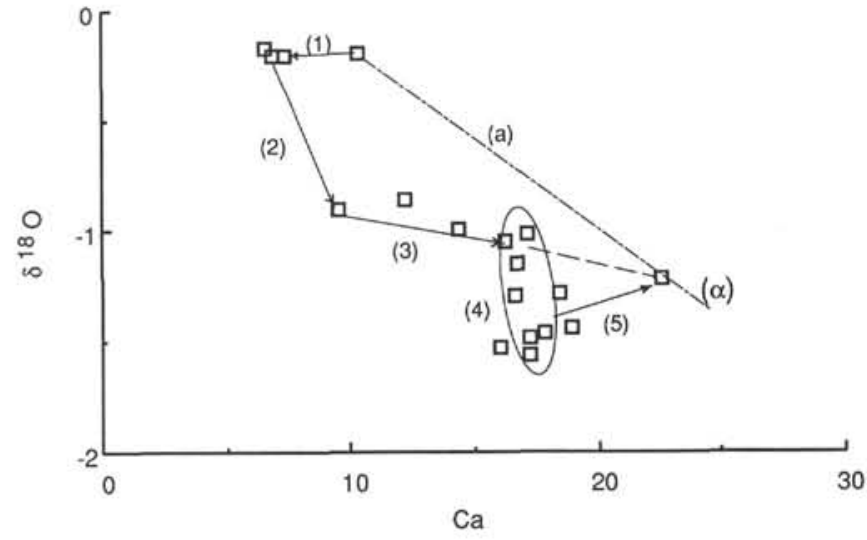

Figure $8 . \delta^{18} \mathrm{O}(\% \circ$ vs. SMOW) vs. Ca $(\mathrm{mM})$ in pore waters of Site 717. Evolution with depth is along arrows 1 to 5 . Line " $\mathrm{a}$ " corresponds to $d \delta^{18} \mathrm{O} / \mathrm{d} \mathrm{Ca}=-0.08 \% d \mathrm{mM}$. $\alpha$ corresponds to data for $823.2 \mathrm{mbsf}$ at Site 717.

$1 \% \mathrm{mM}^{-1}$. We do not know the meaning of this value. In this area, the small difference in $\mathrm{Ca}$ between the waters at 479.5 and 508 mbsf was interpreted as due to diagenetic formation of $\mathrm{CaCO}_{3}$. It also corresponds to an increase in $d \delta^{18} \mathrm{O}$, which is compatible with present $\mathrm{CaCO}_{3}$ precipitation at the local temperature of about $20^{\circ} \mathrm{C}$.

5. The pore-water composition is, therefore, located on a tie line between area 4 and the composition of the pore water at $823.2 \mathrm{mbsf}$. The $\mathrm{Ca}-\delta^{18} \mathrm{O}$ composition of this latter corresponds to seawater which should have had calcium enrichment accompanied by decrease in $\delta^{18} \mathrm{O}$ with $d \delta^{18} \mathrm{O} / d \mathrm{Ca}=$ $-0.8 \%$ o $\mathrm{mM}^{-1}$; which corresponds to the relation found in the DSDP pore waters influenced by submarine weathering of the oceanic crust (Laurence, 1989) (line "a" in Fig. 8).

The way we have presented this description of $\delta^{18} \mathrm{O}-\mathrm{Ca}$ relationships at Site 717 is justified by previous results. The study of the major elements in the pore waters at this site suggests that the fluid composition at $823.2 \mathrm{mbsf}$ was due to upwelling of water issued at least partly from the basaltic basement (Shipboard Scientific Party, 1989a). The tie line 3 suggests that this hot fluid may have affected pore waters at shallower depths. This implies that still more buoyant upwelling of hot fluid may have occurred in the past, an implication that is compatible with the $\delta^{18} \mathrm{O}-\delta^{13} \mathrm{C}$ data of the carbonate cements (Boulègue and Mariotti, in press and this volume).

At Site 718 the main features of the $\delta^{18} \mathrm{O}-\mathrm{Ca}$ relationships are the following (Fig. 9).

1. Between 1.5 and 4.5 mbsf there is a decrease in both $\mathrm{Ca}$ and $\delta^{18} \mathrm{O}$ (the temperature effect corresponds to less than $15^{\circ} \mathrm{C}$ ), which would imply precipitation of $\mathrm{CaCO}_{3}$. At 90.5 mbsf, the $\delta^{18} \mathrm{O}$ and $\mathrm{Ca}$ values are quite different and in agreement with the upwelling of hot water and expansion in the sand layers found at this depth range. Between 107.3 and $124.8 \mathrm{mbsf}$, the $\delta^{18} \mathrm{O}$ and Ca data are again very close to those in water at 1.5 mbsf. This would also support the downwelling of bottom seawater at this depth range, which was deduced from the shipboard chemical and thermal data (Shipboard Scientific Party, 1989b).

2. Between 124.8 and 162.8 mbsf a large negative shift in $\delta^{18} \mathrm{O}$ is observed, as already noticed.

3. Between 162.8 and 525.3 mbsf, the concentration of $\mathrm{Ca}$ increases, with little decrease in $\delta^{18} \mathrm{O}$ (Line " 3 " in Fig. 9). Below this the $\delta^{18} \mathrm{O}$ decrease is larger and the waters between 


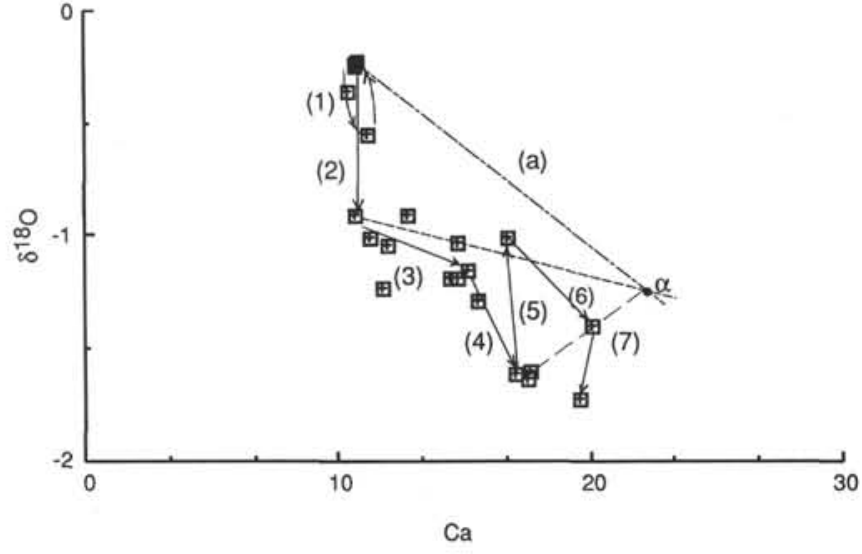

Figure $9 . \delta^{18} \mathrm{O}$ (\%o vs. SMOW) vs. Ca (mM) in pore waters of Site 718. Evolution with depth is along arrows 1 to 7 . Others, same as Figure 8.

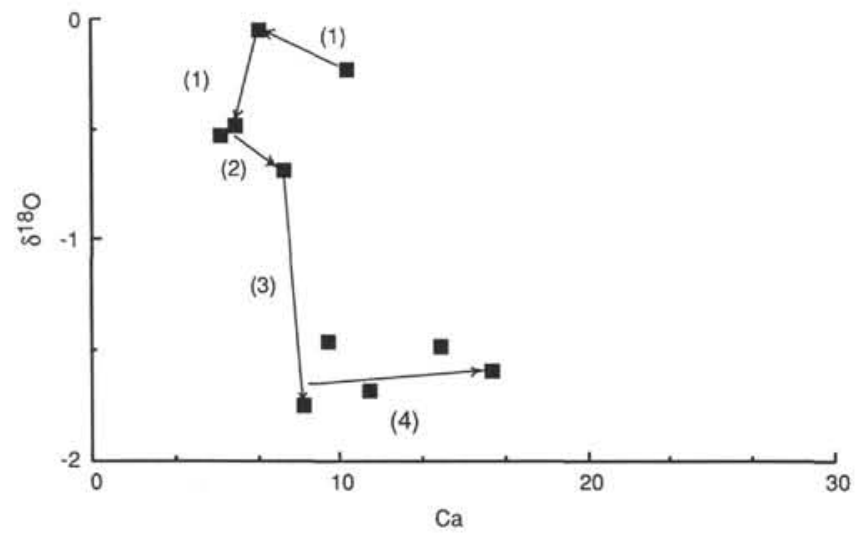

Figure $10 . \delta^{18} \mathrm{O}(\% \circ$ vs. SMOW) vs. Ca $(\mathrm{mM})$ in pore waters of Site 719. Evolution with depth is along arrows 1 to 4 .

523.3 and 800 mbsf are found on line " 4 " in Figure 9. The ${ }^{18} \mathrm{O}$ and $\mathrm{Ca}$ values in waters at $647.3,704.3$, and $800 \mathrm{mbsf}$ are very close to those found at 479.5 mbsf in Site 717, which we noticed as the extreme composition of area 4 in Figure 8. Between 800 and $856.3 \mathrm{mbsf}$ the $\mathrm{Ca}-\delta^{18} \mathrm{O}$ evolution follows $d \delta^{18} \mathrm{O} / d \mathrm{Ca}=1 \% \circ \mathrm{mM}^{-1}$, so that line " 5 " in Figure 9 is the same as the mean slope of area 4 of Figure 8 ; the $\delta^{18} \mathrm{O}-\mathrm{Ca}$ data at 856 mbsf, Site 718 , being the same as at 571.4 mbsf at Site 717. In this area the negative variation of $\mathrm{Ca}$, combined with a small negative shift of $\delta^{18} \mathrm{O}$ between 191.3 and $238.8 \mathrm{mbsf}$, may be attributed to carbonate precipitation.

4. At $893.5 \mathrm{mbsf}$ the $\mathrm{Ca}-\delta^{18} \mathrm{O}$ data could be interpreted as being on a tie line between a composition equivalent to 823.2 mbsf at Site 717 (point $\alpha$ in Figs. 8 and 9) and the more negative $\delta^{18} \mathrm{O}$ waters found in area 4 (Fig. 8) or that found between 704.3 and $800 \mathrm{mbsf}$ at Site 718 . This suggests that part of the fluid may have been derived from upwelling water, in agreement with the chemical data (Shipboard Scientific Party, 1986b). The water found at 920 mbsf has mostly a slightly more negative $\delta^{18} \mathrm{O}$.

At Site 719 , the main features of the $\delta^{18} \mathrm{O}-\mathrm{Ca}$ relationships are the following (Fig. 10).

1. There is a decrease in both $\delta^{18} \mathrm{O}$ and $\mathrm{Ca}$ in the upper part that implies precipitation of carbonate, at least between 60 to 119.7 mbsf. At $181.2 \mathrm{mbsf} \mathrm{Ca}$ has again increased (see paths "1" and "2"' in Fig. 10).
2. Between 181.2 and 205 mbsf a strong negative shift of $\delta^{18} \mathrm{O}$ occurs. This is correlated with similar shifts at Sites 717 and 718 , as already noted.

3. Below this, Ca content of pore waters increases for an almost constant $\delta^{18} \mathrm{O}$. This may signify that diagenetic effects (decrease of $\delta^{18} \mathrm{O}$ ) are compensated by dissolution of biogenic carbonates (increase of $\delta^{18} \mathrm{O}$. At depth $435 \mathrm{mbsf}$, the $\mathrm{Ca}-\delta^{18} \mathrm{O}$ data are very close to the lower extremity of area 4 defined at Sites 717 and 718 (Fig. 8).

The Ca- $\delta^{18} \mathrm{O}$ relationships can be examined so as to find $\mathrm{Ca}$-similarities between the three holes. The $\delta^{18} \mathrm{O}-\mathrm{Ca}$ diagram for all samples is presented in Figure 11. This diagram displays the following characteristics in addition to those described above.

1. The evolution of the waters at Site 719 leads generally to more extreme values. This is attributed to the fact that hyperfiltration-osmotic effects have been more acute in this hole as noted with the $\delta^{18} \mathrm{O}-\delta^{2} \mathrm{H}$ data. Nevertheless, some common features appear between the samples at 435 mbsf in $719,704.3$ and 800 mbsf in 718 and 479.5 mbsf at Site 717.

2. Lines 3 in Figures 8 and 9 are very close and a common $\delta^{18} \mathrm{O}-\mathrm{Ca}$ behavior exist for most of the samples between 270.5 and $665 \mathrm{mbsf}$ at Site 717 and between 162.8 and $800 \mathrm{mbsf}$ at 718 .

3. Few samples show clear evidence that upwelling of hot water has been important in addition to membrane filtration and related effects. Only the sample at $823.2 \mathrm{mbsf}$ at Site 717 is clearly on the $\delta^{18} \mathrm{O}$-Ca trend (line " $a$ " in Fig. 11) defined for seawater-basalt interaction (Laurence, 1989). However, the tie line that was drawn between this sample (point " $a$ " in Fig. 11) and the 893.5 mbsf sample at Site 718 suggests that the $\delta^{18} \mathrm{O}-\mathrm{Ca}$ features of other samples may also be influenced to some extent by this phenomenon. For instance, line 3 from Figure 9 intersects line " $a$ " at the same point " $\beta$ " as the line joining the samples with extreme $\delta^{18} \mathrm{O}$ values. Point ' $\beta$ " ' $(28.7$ $\mathrm{mM} ;-1.71 \%$ ) and point " $\mathrm{a}$ ", although different, are quite close if considered from the point of view of the extent of basalt-seawater interactions as modeled by Laurence (1989). Hence we suggest that the $\delta^{18} \mathrm{O}$-Ca relationships found in Sites 717,718 , and 719 can be explained by a combination of upwelling of hot water that has reacted with basalt and of water isotopically modified by membrane filtration and related

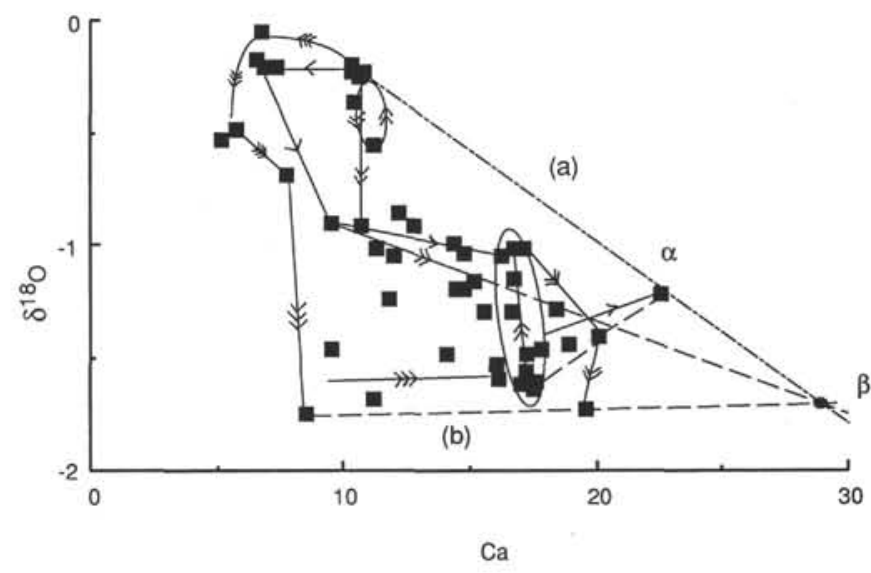

Figure 11. $\delta^{18} \mathrm{O}(\% \circ$ vs. SMOW) vs. $\mathrm{Ca}(\mathrm{mM})$ in pore waters of Sites 717,718 , and 719. Evolution with depth is along single, double, and triple arrows for Sites 717,718 , and 719 , respectively. Line " $b$ " is the tie line between lowest $\delta^{18} \mathrm{O}$ data. $\beta$ point has coordinates $28.7 \mathrm{mM}$, $-1.71 \%$. Others, same as Figure 8 . 
effects; the extreme data following both trends being represented respectively by lines " $a$ " and "b" in Figure 11.

4. The $\delta^{18} \mathrm{O}-\mathrm{Ca}$ relationship for all samples is $\delta^{18} \mathrm{O}=$ $0.10-0.083 \mathrm{Ca}(\mathrm{r}=0.69)$. The $d \delta^{18} \mathrm{O} / d \mathrm{Ca}$ is close to that of line " $a$ ". This also suggests that upwelling and expansion of deep pore water has probably occurred, as proposed on the basis of the chemical analyses (Shipboard Scientific Party, $1989 \mathrm{a}, \mathrm{b}$; Boulègue and Mariotti, in press and this volume).

\section{$\delta^{18} \mathrm{O}-\mathrm{Mg}$ and $\boldsymbol{\delta}^{2} \mathrm{H}-\mathrm{Mg}$ Relationships}

The $\delta^{18} \mathrm{O}-\mathrm{Mg}$ relationship for all data is significant and shows the general trend, $\delta^{18} \mathrm{O}=-25+0.44 \mathrm{Mg}(\mathrm{R}=0.78)$ (Fig. 12). Some samples fall slightly off this line: those from the top of Sites 717 and 719 , where $\mathrm{Mg}$ decreases by about $10 \mathrm{mM}$ due to presumed carbonate precipitation, and samples from the bottom at Site 719. A good relationship can be found at Site 718 (Fig. 13); $\delta^{18} \mathrm{O}=-2.5+0.043 \mathrm{Mg}(\mathrm{r}=$ $0.93)$. The difference between the ratio $\mathrm{Mg} / \delta^{18} \mathrm{O}$ with the ratio $\mathrm{Ca} / \delta^{18} \mathrm{O}$ reflects almost twice as large a decrease in $\mathrm{Mg}$ compared with the increase of $\mathrm{Ca}$ in the pore waters (Shipboard Scientific Party, 1989a, b, c). This might be related to diagenetic changes within the sediment column, for example, extensive alteration of volcanic ash, while the source of calcium, provided by upwelling of deep pore

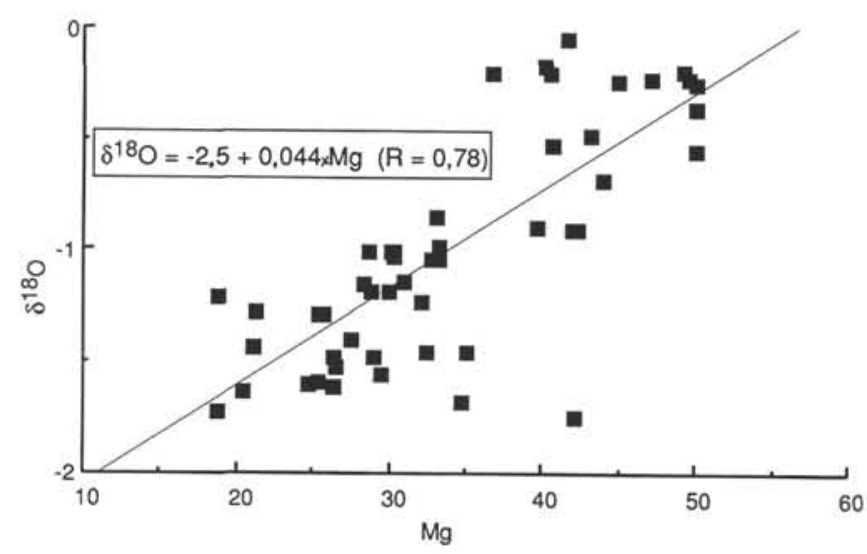

Figure $12 . \delta^{18} \mathrm{O}(\% \circ$ vs. SMOW) vs. $\mathrm{Mg}(\mathrm{mM})$ in pore waters of Sites 717,718 , and 719 , with regression line.

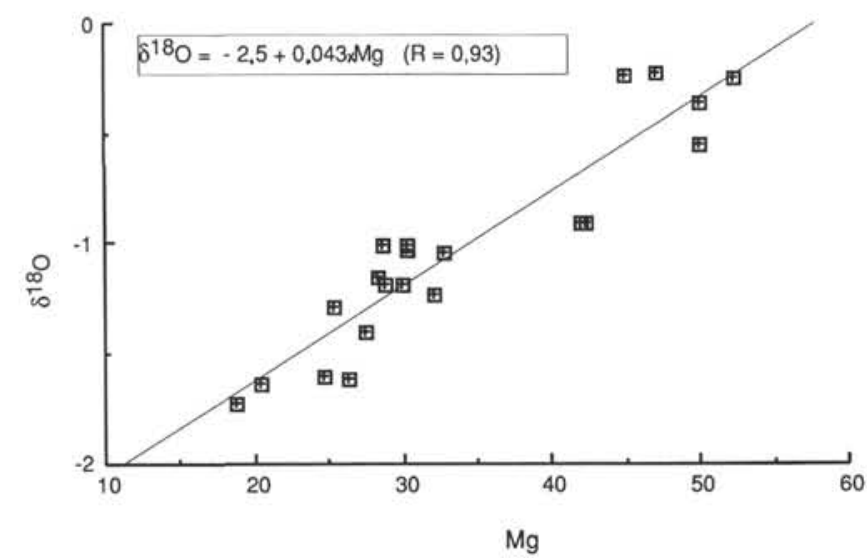

Figure 13. $\delta^{18} \mathrm{O}(\% \circ$ vs. SMOW) vs. $\mathrm{Mg}(\mathrm{mM})$ in pore waters of Site 718 , with regression line. water, has ceased in all but a few deep layers. This interpretation is in agreement with that of the $\delta^{18} \mathrm{O}-\mathrm{Ca}$ relationships and the $\delta^{13} \mathrm{C}-\delta^{18} \mathrm{O}$ data of the carbonate cements (Boulègue and Mariotti, in press and this volume). However, there is no lithologic evidence from the cores recovered for much volcanic ash nor for significant early diagenesis in the upper parts of the three sites.

The $\delta^{2} \mathrm{H}-\mathrm{Mg}$ relation for all the data is of quite good quality: $\delta^{2} \mathrm{H}=-12+0.18 \mathrm{Mg}(\mathrm{R}=0.81)$ (Fig. 14). Here again this is probably best explained by hyperfiltration-osmotic effects, especially because hydrogen is not affected by other processes such as carbonate precipitation, which causes oxygen isotope variations.

\section{CONCLUSIONS}

The oxygen and hydrogen isotope ratios in the pore waters of the three Leg 116 sites have enabled us to acquire independent information on processes that had been inferred on the basis of the chemical analyses (Shipboard Scientific Party, $1989 \mathrm{a}, \mathrm{b}, \mathrm{c})$.

1. The $\delta^{18} \mathrm{O}-\delta^{2} \mathrm{H}$ relationships show that hyperfiltrationosmotic effects are important and influence most of the samples. The $\delta^{2} \mathrm{H}-\mathrm{Mg}$ relationships probably indicate similar effects.

2. Toward the top of all sites, and especially Sites 717 and 719 , the $\delta^{18} \mathrm{O}$ and $\delta^{2} \mathrm{H}$ data are compatible with the expulsion of water from the interlayers of montmorillonite, combined with membrane filtration effects. The diagnetic precipitation of carbonate, $(\mathrm{Ca}-\mathrm{Mg}) \mathrm{CO}_{3}$, is also thought to have influenced the $\delta^{18} \mathrm{O}$ data in the upper parts of all sites.

3. The $\delta^{18} \mathrm{O}-\mathrm{Ca}$ data as well as $\delta^{2} \mathrm{H}$ data from Site 718 are compatible with the hot water into the upper sandy section, as well as the downwelling of deep seawater into the underlying section, as was proposed on the basis of the shipboard chemical data.

4. In places, the $\delta^{18} \mathrm{O}-\mathrm{Ca}$ data suggest that diagenetic precipitation of carbonate has occurred, in agreement with saturation calculations deduced from chemical data.

5. The results of comparison of $\delta^{18} \mathrm{O}-\mathrm{Ca}$ and $\delta^{18} \mathrm{O}-\mathrm{Mg}$ relationships is further evidence for the upwelling of hot fluid into numerous sediment layers of the upper part of the sediment column. We think that subsequent diagenetic changes have continued to affect the $\delta^{18} \mathrm{O}$ and $\mathrm{Mg}$ concentrations.

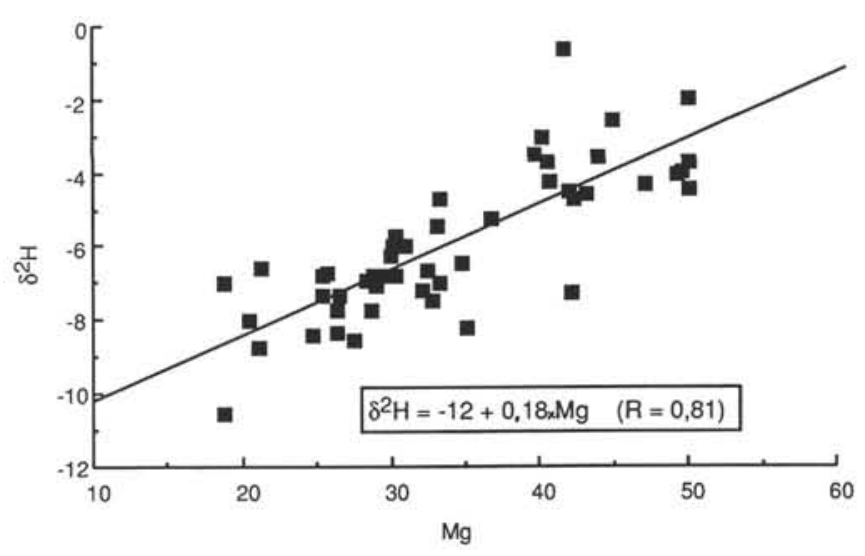

Figure 14. $\delta^{2} \mathrm{H}$ (\%o vs. SMOW) vs. $\mathrm{Mg}(\mathrm{mM})$ in pore waters of Sites 717,718 , and 719 , with regression line. 


\section{REFERENCES}

Bigeleisen, J., Perlman, M. L., and Broosen, H. C., 1952. Conversion of hydrogenic materials to hydrogen for isotopic analysis. Anal. Chem., 24:1356.

Boulègue, J., and Mariotti, A., in press. Carbonate cements and fluid circulation in intraplaque deformation. Chem. Geol.

Coplen, T. B., and Hanshaw, B. B., 1973. Ultrafiltration by a compacted clay membrane. I. Oxygen and hydrogen isotopic fractionation. Geochim. Cosmochim. Acta, 37:2295-2310.

Epstein, S., and Mayeda, T., 1953. Variation of ${ }^{18} \mathrm{O}$ of waters from natural sources. Geochim. Cosmochim. Acta, 4:213-224.

Geller, C. A., Weissel, J. K., and Anderson, R. N., 1983. Heat transfer and intraplate deformation in the central Indian Ocean. $J$. Geophys. Res., 88:1018-1032.

Laurence, J. R., 1989. The stable isotope geochemistry of deep-sea pore water. In Fritz, P., and Fontes, J. Ch. (Eds.), Handbook of Environmental Isotope Geochemistry (Vol. 3): Amsterdam (Elsevier), 317-356.
Shipboard Scientific Party, 1989a. Site 717: Bengal Fan. In Cochran, J. R., Stow, D.A.V., et al., Proc. ODP, Init. Repts., 116: College Station, TX (Ocean Drilling Program), 45-90.

1989b. Site 718: Bengal Fan. In Cochran, J. R., Stow, D.A.V., et al., Proc. ODP, Init. Repts., 116: College Station, TX (Ocean Drilling Program), 91-154.

1989c. Site 719: Bengal Fan. In Cochran, J. R., Stow, D.A.V., et al., Proc. ODP, Init. Repts., 116: College Station, TX (Ocean Drilling Program), 155-196.

Date of initial receipt: 5 February 1990

Date of acceptance: 5 February 1990

Ms 116B-133 